\title{
Modeling Biological Oxygen Demand Load Capacity in a Data-Scarce Basin with Important Anthropogenic Interventions
}

\author{
Alejandra Zurita ${ }^{1, *}$, Mauricio Aguayo ${ }^{2} \mathbb{D}$, Pedro Arriagada ${ }^{1}$, Ricardo Figueroa ${ }^{3} \mathbb{D}$, María Elisa Díaz ${ }^{3,4}$ \\ and Alejandra Stehr $1, *$ D
}

1 Centro de Ciencias Ambientales EULA-Chile, Departamento de Ingeniería Ambiental, Facultad de Ciencias Ambientales, Universidad de Concepción, Concepción 4070386, Chile; parriagada@udec.cl

2 Centro de Ciencias Ambientales EULA-Chile, Departamento de Planificación Territorial, Facultad de Ciencias Ambientales, Universidad de Concepción, Concepción 4070386, Chile; maaguayo@udec.cl

3 Centro de Ciencias Ambientales EULA-Chile, Departamento de Sistemas Acuáticos, Facultad de Ciencias Ambientales, Universidad de Concepción, Concepción 4070386, Chile; rfiguero@udec.cl (R.F.); mdiaz@uct.cl (M.E.D.)

4 Laboratorio de Limnología y Recursos Hídricos, Departamento de Ciencias Ambientales, Universidad Católica de Temuco, Temuco 4813302, Chile

* Correspondence: alejandrazurita@udec.cl (A.Z.); astehr@udec.cl (A.S.)

check for

updates

Citation: Zurita, A.; Aguayo, M.; Arriagada, P.; Figueroa, R.; Díaz, M.E.; Stehr, A. Modeling Biological Oxygen Demand Load Capacity in a

Data-Scarce Basin with Important Anthropogenic Interventions. Water 2021, 13, 2379. https://doi.org/ 10.3390/w13172379

Academic Editor: Luca

Giovanni Lanza

Received: 6 July 2021

Accepted: 25 August 2021

Published: 30 August 2021

Publisher's Note: MDPI stays neutral with regard to jurisdictional claims in published maps and institutional affiliations.

Copyright: (c) 2021 by the authors. Licensee MDPI, Basel, Switzerland. This article is an open access article distributed under the terms and conditions of the Creative Commons Attribution (CC BY) license (https:// creativecommons.org/licenses/by/ $4.0 /)$.

\begin{abstract}
Most water bodies are currently used as receptors for pollutants coming mainly from the industrial and domestic sectors. The Biobío river is subjected to multiple anthropogenic pressures such as industrial water supply, drinking water, hydroelectric power generation, agriculture, and the final receptor body of a large amount of industrial and urban waste, pressures that will intensify due to the decrease in water flow as a result of climate change. In this context, organic contamination has been found mainly from sewage discharges and oxidizable waste discharges generated by industrial processes. In this sense, the objective of this research is to determine the Biological Oxygen Demand Loading Capacity (LC) in a basin with a low density of water quality data subjected to strong anthropogenic pressures. To estimate the carrying capacity in a section of the Biobío River, the water quality model River and Stream Water Quality Model- Qual2K version 2.11b8, developed by Chapra, was used. This model solves the Streeter-Phelps equation, proposing an analytical expression to relate the dissolved oxygen (DO) and biochemical oxygen demand $\left(\mathrm{BOD}_{5}\right)$ variables. These variables were modeled for different critical scenarios of minimum flows in return periods of 5, 50, and 100 years, determining that the studied section of the Biobío river would have a high carrying capacity to not be affected by its organic matter pollution.
\end{abstract}

Keywords: Biobío river; load capacity; water quality; Qual2K

\section{Introduction}

Global freshwater demand has shown an average growth of $1 \%$ per year since the 1980s, mainly due to economic and population growth [1]. The sectors with the highest global water consumption are: agriculture, accounting for $69 \%$ of annual water withdrawals, the industrial sector with $19 \%$, and domestic consumption with $12 \%$, and this is expected to increase by $20-30 \%$ by 2050 [1]. In this sense, the overexploitation of water resources has generated severe environmental problems, e.g., water pollution, loss of aquatic habitat, fragmentation of ecosystems, and others, all associated with the anthropic pressures reducing the quantity and quality of available water [2-5].

The Latin American and Caribbean region has 31\% of the world's freshwater resources [5]. However, water pollution is a problem that is increasing due to continued urbanization and economic development [1]. Although the agricultural sector is the largest 
consumer of water, the urban and industrial sectors are the largest emitters of toxic substances to water bodies, with wastewater discharges being the primary source of pollution and loss of water quality $[3,5,6]$.

The quality of water bodies depends on natural processes such as climatological conditions (e.g., precipitation, temperature), soil types, vegetation cover, erosion, runoff, and the loss of water due to anthropogenic pressures; exploitation of water resources, changes in land use (agriculture), industrial activities, and urban settlements [7-9].

Additionally, the main effect of climate change in freshwater bodies is to increase the frequency of extreme events, especially droughts, increasing the concentrations of pollutants present in surface water bodies $[10,11]$. Droughts, reduced flow rates and increased water temperature cause a decrease in dissolved oxygen, altering the dilution and self-purification capacity in rivers expressed as an increase in suspended biochemical oxygen demand [12].

Dissolved oxygen is an indicator of the quality and health of aquatic ecosystems [13-21], as well as of the self-purification processes of natural systems [17,18,22-24]. Self-purification is a slow process, which depends on the: (a) flow rate, (b) water movement, and (c) depth and surface area of the water body. In this sense, if the concentration of the pollutant is very high, the water flow is required to travel long distances before achieving acceptable concentrations [22,24-26].

Load capacity (LC) is a concept frequently used in river water quality management, which is defined as the maximum quantity of a particular substance that can exist in a receptor body without altering the ecological characteristics of the system $[27,28]$. The US EPA, through the Clean Water Act (CWA), proposes the Total Maximum Daily Load (TMDL) as an indicator of LC [29-31]. This concept is defined as the maximum daily concentration possible to discharge into a water body to meet specific environmental quality standards at a given location. Additionally, it is possible to quantify this load in other temporal scales such as monthly, seasonal, or annual [29,30,32-35].

Over the years, water quality models have been developed as a fundamental tool in the prediction and control of pollutants due to their ability to represent biological, chemical, and physical processes and changes in aquatic ecosystems [32,36]. The most used models are QUAL2K [16,32], MIKE11 [37], HEC-RAS [38,39], and SWAT [40,41], which predict the behavior of river water quality using hydrology and hydraulics variables and pollutants characteristics [42]. However, the application of these models faces significant challenges due to the large amount of detailed and spatialized data required, e.g., land use, time series of pollutant concentration, daily flows series, and samples along the river. Information frequently is not available in developing countries, which are often limited and can have significant uncertainties [42-45].

In this context, the objective of this research is to determine the Biological Oxygen Demand LC in a basin with a low density of water quality data subjected to strong anthropogenic pressures. The Biobío river basin in Chile was selected for this purpose, due to its low density of information and the multiple anthropogenic pressures to which it is subjected, such as industrial water supply, drinking water, hydroelectric power generation, agriculture, and final receptor body of a large amount of industrial and urban waste.

\section{Study Area}

\section{Study Basin}

The Biobío river basin is located in south-central Chile, specifically between coordinates $36^{\circ} 45^{\prime}-38^{\circ} 49^{\prime} \mathrm{S}$ and $71^{\circ} 00^{\prime}-73^{\circ} 20^{\prime} \mathrm{W}$ (Figure 1). It covers an area of $24,260 \mathrm{~km}^{2}$, being the third largest basin in the country. The main channel is $380 \mathrm{~km}$ and is the second-longest river in Chile [46]. It is also located between two political-administrative regions: the Biobío Region (72\% of the total area) and the Araucanía Region (28\%) [47]. The hydrological regime of the Biobío basin is pluvio-nival, with an average flow at its source being $30 \mathrm{~m}^{3} / \mathrm{s}$ [47] and average flow at its mouth being $960 \mathrm{~m}^{3} / \mathrm{s}$, with a maximum and minimum flow average of $1600 \mathrm{~m}^{3} / \mathrm{s}$ (July) and $160 \mathrm{~m}^{3} / \mathrm{s}$ (March) [48]. In addition, it is subject to the 
influence of different environments and geographical factors, causing the dynamics of the system to be highly variable from the beginning of its course to its mouth [47-49].

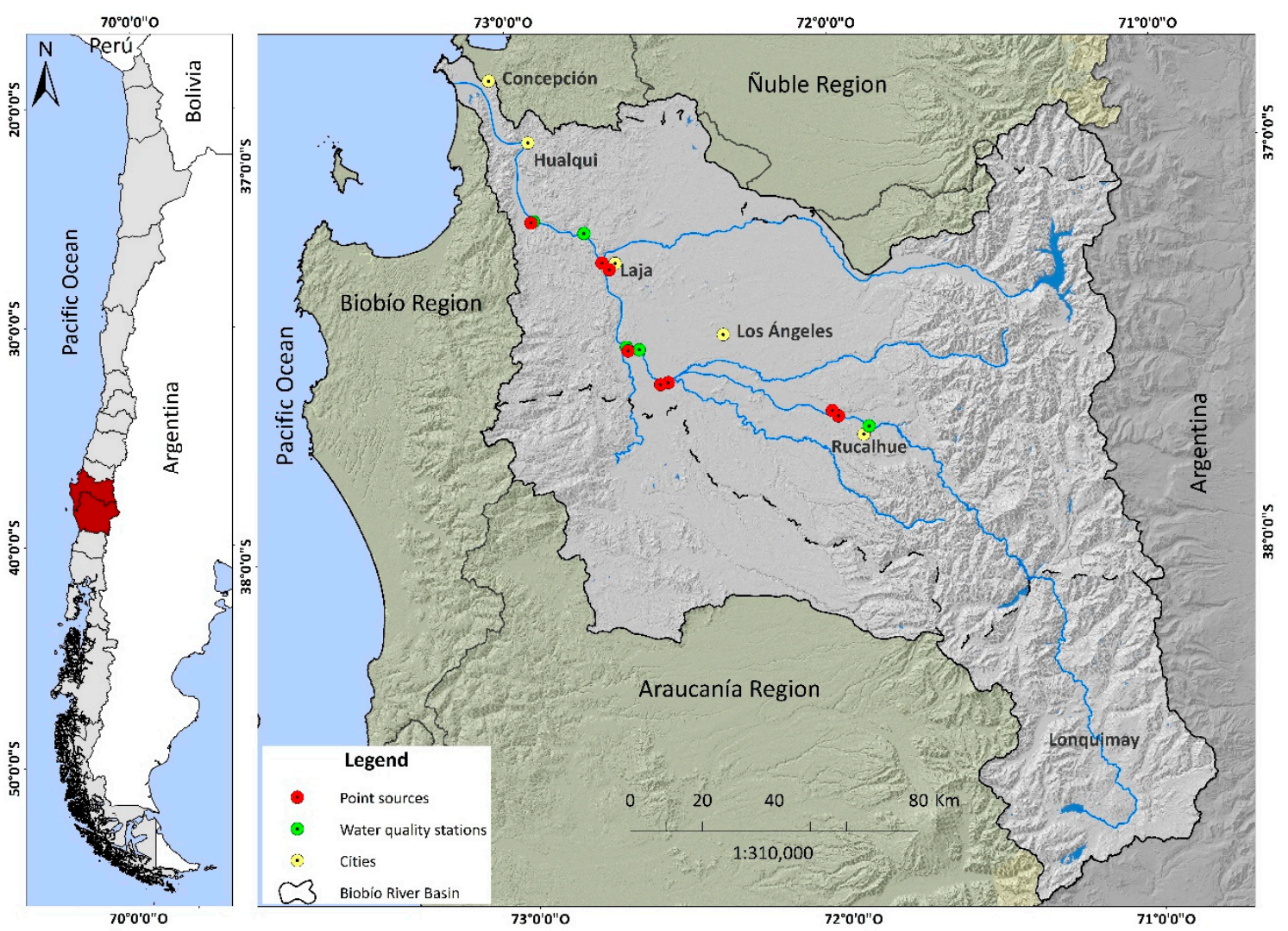

Figure 1. Location of the Biobío river basin.

This study considers a $159.6 \mathrm{~km}$ of the Biobío River between the cities of Rucalhue and Hualqui (Figure 1). The selection of the section considered the existence of different point sources (sewage treatment plants and industrial effluents). The fluviometric and water quality records were obtained from the Chilean Water Authority (DGA) [50] and the Biobío River Monitoring Program (PMBB) of the EULA (European-Latin America) Center-Chile.

\section{Water Quality Legislation in Chile}

In 2004, Chile began issuing Secondary Environmental Quality Standards (NSCA) to ensure the protection and conservation of aquatic ecosystems of inland surface waters and reduce pollution and maintain their quality as much as possible. Currently, five Secondary Standards have been issued, two for lake bodies (Lago Llanquihue and Lago Villarrica), and three for river basins (the Serrano river basin, Maipo river basin, and Biobío river basin) [51].

The secondary environmental quality standard for the Biobío river basin aims to conserve or preserve aquatic ecosystems and their ecosystem services by maintaining or improving water quality in the basin. Therefore, environmental quality standards were established for 19 pollutants, including $\mathrm{DO}$ and $\mathrm{BOD}_{5}$. Fourteen monitoring areas were implemented to comply with the standards, six along the Biobío River and eight in its main tributaries [51,52].

\section{Water Quality Model}

The most widely used method for determining the variation of $\mathrm{DO}, \mathrm{BOD}$, and loading capacity concentrations in a river course is the Streeter and Phelps (1925) model [53]. The empirical equations proposed by these researchers have been widely used to evaluate the 
impact of waste discharges on dissolved oxygen concentrations and assimilative capacity in rivers [14,16,53-59]. Currently, a large number of water quality models solve the equations developed by Streeter and Phelps, the most widely applied being the River and Stream Water Quality Model- Qual2K [16,17,32,35,60,61]. This one-dimensional mathematical model assumes complete mixing of the flow in both vertical and transverse directions and divides the reach of interest into a specific number of computational elements with homogeneous hydraulic characteristics [62-65].

In the study section, the $159.6 \mathrm{~km}$ river reach was divided into seven sections with similar hydraulic characteristics, i.e., slope, width, and elevation (Figure 2). For this purpose, ArcGis 10.1 software was used with a $30 \times 30$-m-resolution digital elevation model (DEM) that was obtained from the Shuttle Radar Topography Mission [66]. Given the complexity of the system, the average velocity and depth of water flow in the study section were determined using the River Analysis System (Hec-Ras) 4.0 model developed by the Hydrologic Engineering Center of the U.S. Army Corps of Engineers [16].

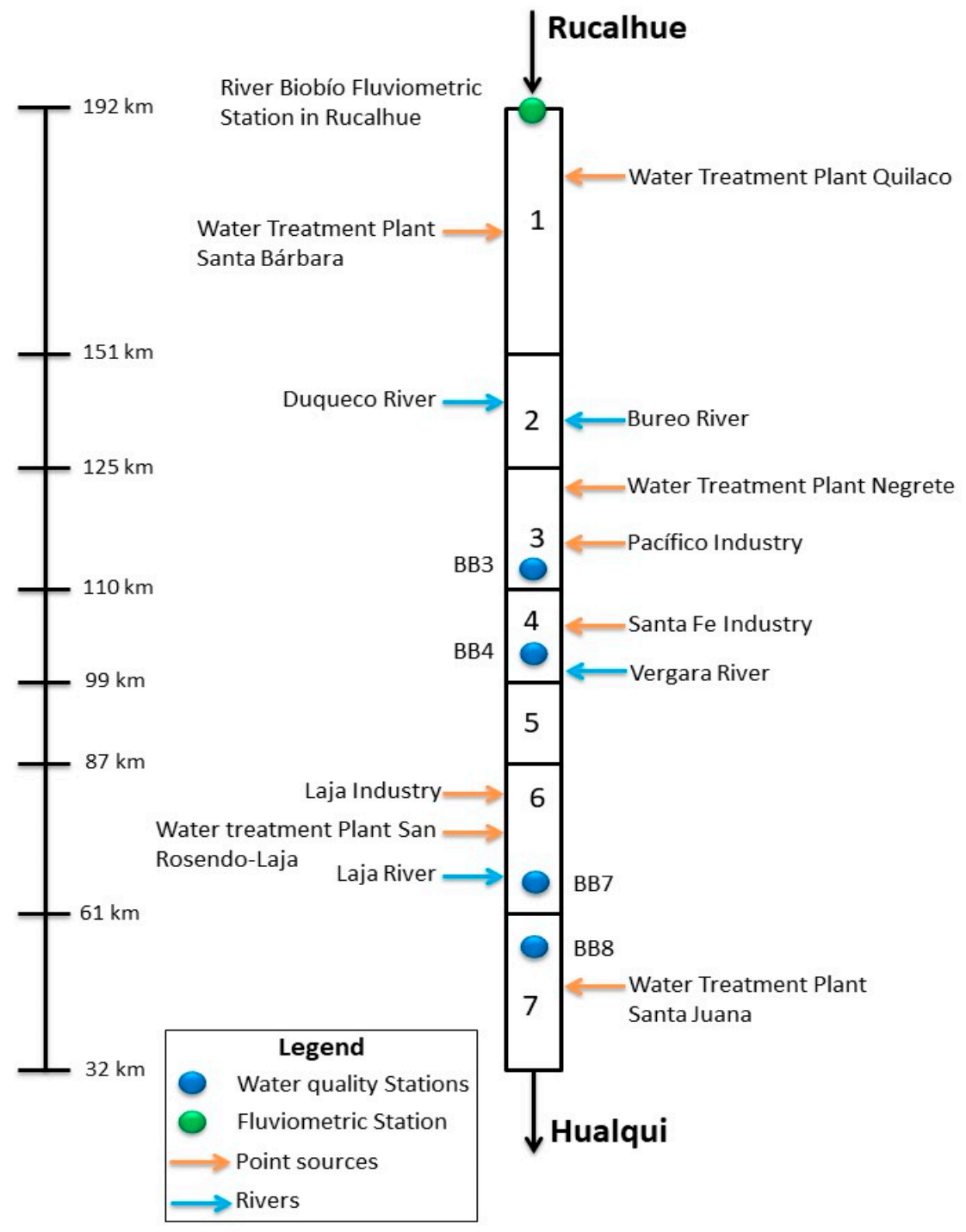

Figure 2. Conceptual diagram of the study of Biobío reach.

The calibration and validation of the model were carried out with data from the monthly DO concentrations of the PMBB water quality stations. The calibration process was performed for March 2009, calibrating the parameters $k_{a}$ (Reaeration Coefficient), $k_{d}$ (Deoxygenation Coefficient), and the temperature correction coefficients $\theta_{\mathrm{a}}$ and $\theta_{\mathrm{d}}$ [65]. 
The validation period was for March 2012. The goodness of fit (GoF) indicators Coefficient of Determination $\left(R^{2}\right)$, Nash-Sutcliffe Efficiency (NSE), Percent Bias (PBIAS), and the Agreement Index (d) [19,67-69] were used for calibration and validation periods. Finally, The $\mathrm{LC}$ of $\mathrm{BOD}_{5}$ was evaluated for the extreme drought flows with return periods of 5, 50, and 100 years. The fluviometric record of the Biobío River Station in Rucalhue (BNA code 08317001-8) [50] from 1960 to 2013 was used for this analysis [70].

To determine the maximum BOD concentration that can be purified by the Biobío River in extreme minimum flow scenarios, a minimum DO concentration of $5 \mathrm{mg} / \mathrm{L}$ was considered. This value is determined in Chilean Standard NCh 1.333 [71], which establishes water quality criteria according to physical, chemical, and biological aspects, depending on the user assigned to the water body.

\section{Results and Discussion}

Table 1 shows the GoFs indicators results in the calibration and validation phases. The model performance during calibration can be classified as very good, in the case of $\mathrm{R}^{2}$, NSE, and d indicators, and satisfactory in the case of PBIAS, according to Moriasi et al. (2015) [68]. In the validation period, $\mathrm{R}^{2}$ decreases to good and PBIAS changes to underestimation; according to Moriasi et al. (2015) [68], the other GoF remained in the same category. These results show that the efficiency criteria of the model are high, which indicate that the Qual2K acceptably represents the behavior of the variables studied for the study section of the Biobío River but tends to underestimate the DO concentration. Finally, Table 2 shows the values obtained for the parameters $k_{a}, k_{d}, \theta_{a}$, and $\theta_{d}$ for the seven sections used.

Table 1. Statistical indicators for the calibration and validation processes for the Biobío River study section.

\begin{tabular}{cccc}
\hline Statistical Indicators & Calibration & Validation & Correlation \\
\hline $\mathrm{R}^{2}$ & 0.999 & 0.845 & Optimum value 1 \\
NSE & 0.987 & 0.832 & Optimum value 1 \\
PBIAS & 0.225 & -0.291 & Optimum value 0 \\
d & 0.998 & 0.985 & Optimum value 1 \\
\hline
\end{tabular}

Table 2. Values obtained by calibration for the Reaeration Coefficient, Deoxygenation, and Temperature Correction Factor that govern the system in the studied section of the Biobío river.

\begin{tabular}{ccccc}
\hline Section & $\mathbf{k}_{\mathbf{a}}\left(\mathbf{d}^{-\mathbf{1}}\right)$ & $\left.\mathbf{k}_{\mathbf{d}} \mathbf{( d}^{-\mathbf{1}}\right)$ & $\theta_{\mathbf{a}}$ & $\theta_{\mathbf{d}}$ \\
\hline 1 & 0.51 & 0.34 & 1.024 & 1.047 \\
2 & 0.47 & 0.32 & 1.024 & 1.047 \\
3 & 0.20 & 0.32 & 1.024 & 1.047 \\
4 & 6.90 & 0.25 & 1.024 & 1.047 \\
5 & 5.96 & 0.23 & 1.024 & 1.047 \\
6 & 5.54 & 0.38 & 1.024 & 1.047 \\
7 & 1.56 & 0.31 & 1.024 & 1.047 \\
\hline
\end{tabular}

Values obtained by calibration for the different governing parameters for the system (Table 2) show that the $k_{a}$ coefficient presents a high range of variation among the seven sections of the studied reach. This is because the surface reaeration process is one of the primary and variable sources of oxygen in the river system and directly affects DO concentrations. Langbein and Durum (1967) [72] and Bowie et al. (1985) [73] indicated that defining a range for this coefficient is very complex since it depends on factors such as wind speed, temperature, and hydraulic parameters. Similarly, Langbein and Durum (1967) [72] estimated that $k_{a}$ variations are mainly attributable to changes in the hydraulic characteristics of rivers, e.g., width, slope, area, and length of the riverbed, which generate variations in depth and flow velocity, causing the river ecosystem to adopt the conditions for DO concentrations to increase or decrease. They also note that in rivers with high depths, 
the $k_{a}$ value is lower than rivers with shallow depths, concluding that the higher the $k_{a}$ coefficient, the more intense the reaeration process. On the other hand, Link (1998) [74] determined that wastewater discharge into rivers decreases their capacity for reaeration since contaminated water causes the diffusion of DO to be lower. Therefore, the wide range obtained for this coefficient is not surprising since the Biobío River has significant hydraulic differences along its course.

The $k_{d}$ coefficient presented lower variations between sections. However, this parameter did not show significant effects within the DO modeling. This behavior is due to the high dilution capacity of the Biobío River, which is why $\mathrm{BOD}_{5}$ is diluted very quickly when it encounters the water layer, generating a lower oxygen consumption due to BOD degradation. It should also be considered that effluent treatment decreases the oxidizable fraction of BOD, causing its oxidation in the water body to be slower. The temperature correction factor $\theta_{\mathrm{a}}$ was the same for all sections. This factor presented a high incidence in the $\mathrm{DO}$ concentrations, which shows that the DO is sensitive to temperature. The temperature is a factor that affects the reaeration process; increasing the factor decreases the oxygen concentration. As in the previous case, the factor $\theta_{\mathrm{d}}$ had the same value for all the sections. This factor had a low incidence on dissolved oxygen concentrations since it affects oxygen consumption by BOD degradation, specifically the $\mathrm{k}_{\mathrm{d}}$ coefficient.

To determine the extreme drought flow scenarios for return periods of 5, 50, and 100 years, a frequency analysis was performed (Figure 3) for a series of minimum monthly flows available at the Biobío River Station in Rucalhue. The Anderson-Darling goodness of fit test was applied with a 95\% confidence interval [75], as shown in Table 3, using as a criterion the smallest difference between the critical value and the $\mathrm{A}^{2}$ test statistic. The probability distribution that best fit the data series of minimum monthly flows was the Generalized Extreme Value, which gives as results a flow of $82.59 \mathrm{~m}^{3} / \mathrm{s}$ for a 5 -year return period, $66.82 \mathrm{~m}^{3} / \mathrm{s}$ for a 50-year return period, and of $64.32 \mathrm{~m}^{3} / \mathrm{s}$ for a 100 -year return period.

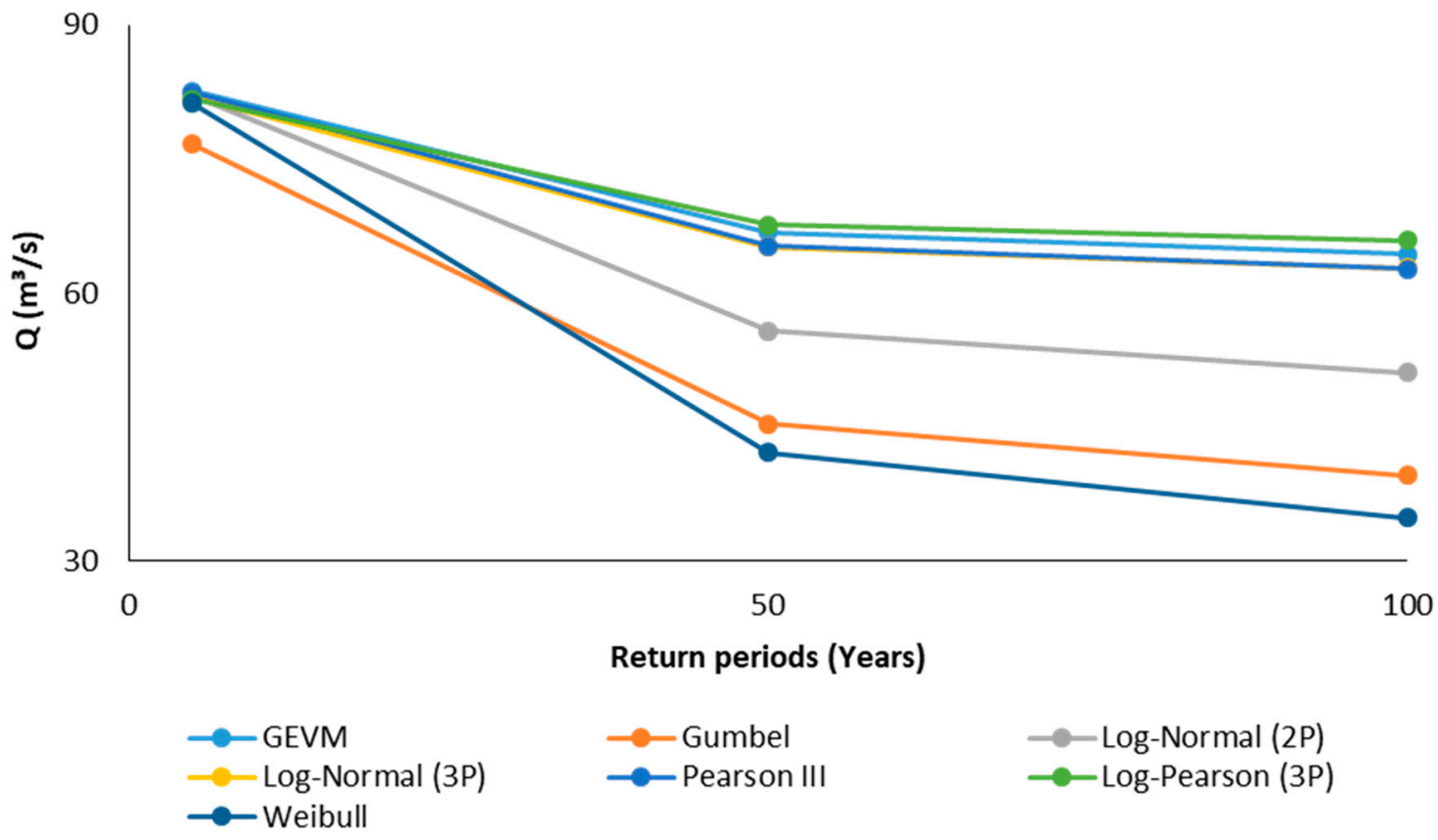

Figure 3. Adjustment of distributions for minimum flows in return periods of 5, 50, and 100 years. 
Table 3. Indicators of fit provided by the Anderson-Darling test.

\begin{tabular}{cccccccc}
\hline & \multicolumn{5}{c}{ Distribution } \\
\cline { 2 - 7 } & GEVM & Pearson III & Log-Normal (3P) & Log-Pearson (3P) & Weibull & Log-Normal (2P) & Gumbel \\
\hline $\mathrm{A}^{2}$ & 0.36 & 0.36 & 0.44 & 0.57 & 1.03 & 1.04 & 1.63 \\
Critical Value & 2.50 & 2.50 & 2.50 & 2.50 & 2.50 & 2.50 & 2.50 \\
Approve & Yes & Yes & Yes & Yes & Yes & Yes & Yes \\
\hline
\end{tabular}

Figure 4 shows the simulations made with Qual2K by the three extreme minimum flow scenarios. Figure 4a shows the DO and BOD concentrations by minimum flow with a return period of 5 years $\left(82.59 \mathrm{~m}^{3} / \mathrm{s}\right)$. The BOD concentration increases downstream, reaching its maximum concentration at $46.3 \mathrm{~km}$, and is equivalent to $1.49 \mathrm{mg} / \mathrm{L}$, while the dissolved oxygen concentration decreases downstream, reaching its minimum concentration at $46.3 \mathrm{~km}$, equal to $8.63 \mathrm{mg} / \mathrm{L}$. Figure $4 \mathrm{~b}$ shows the concentration of DO and BOD for a minimum flow with a return period of 50 years $\left(66.82 \mathrm{~m}^{3} / \mathrm{s}\right)$. It shows that the concentration of dissolved oxygen decreases downstream, reaching a minimum concentration of $8.617 \mathrm{mg} / \mathrm{L}$. The BOD concentration increases downstream, reaching a maximum concentration of $1.55 \mathrm{mg} / \mathrm{L}$ at $46.3 \mathrm{~km}$. Figure $4 \mathrm{c}$ shows the DO and BOD concentration for a minimum flow with a return period of 100 years $\left(64.32 \mathrm{~m}^{3} / \mathrm{s}\right)$. BOD concentration increases downstream, reaching a maximum of $1.56 \mathrm{mg} / \mathrm{L}$ at $46.3 \mathrm{~km}$, while dissolved oxygen concentration decreases, reaching a minimum concentration of $8.615 \mathrm{mg} / \mathrm{L}$ at $46.3 \mathrm{~km}$.

The results show that the highest BOD purification capacity is reached for a minimum flow with a return period of 5 years, equivalent to $82.59 \mathrm{~m}^{3} / \mathrm{s}$ with a concentration of $2078 \mathrm{mg} / \mathrm{L}$. As the return period increases, the BOD concentration that can be purified decreases, reaching the lowest purification capacity in a return period of 100 years, with a minimum flow of $64.32 \mathrm{~m}^{3} / \mathrm{s}$, filtering a maximum concentration of BOD of $1580 \mathrm{mg} / \mathrm{L}$. For the three simulated scenarios, the minimum DO concentration is reached at $104 \mathrm{~km}$ (Table 4). The high load capacity of the Biobío river can be attributed to its high flows, which means that it has a high DBO dilution capacity without considerably altering the aquatic ecosystem, in agreement with reported by [76].

Table 4. Minimum flows for different return periods and maximum BOD concentrations that can be treated by the study section of the Biobío river.

\begin{tabular}{cccc}
\hline T (Years) & $\mathbf{Q}\left(\mathbf{m}^{\mathbf{3}} / \mathbf{s}\right)$ & BOD $_{\max }(\mathbf{m g} / \mathbf{L})$ & Distance $(\mathbf{k m})$ \\
\hline 5 & 82.59 & 2078 & 104 \\
50 & 66.82 & 1679 & 104 \\
100 & 64.32 & 1580 & 104 \\
\hline
\end{tabular}

When comparing the results presented in Figure 4 with the environmental quality levels established in the Secondary Environmental Quality Standard for the Protection of Surface Continental Waters of the Biobío River Basin, in the section from Rucalhue to upstream of the Vergara River (191 to $106.5 \mathrm{~km}$ ) the DO and BOD concentrations obtained for the return periods of 5,50 , and 100 years comply with the environmental quality levels established by monitoring station BI-30, setting a minimum DO concentration of $9 \mathrm{mg} / \mathrm{L}$ and a maximum BOD concentration of $2 \mathrm{mg} / \mathrm{L}$. From upstream of the confluence of the Vergara River to upstream of the confluence with the Gomero River is the BI-40 monitoring station, which establishes a minimum DO concentration of $9 \mathrm{mg} / \mathrm{L}$ and a maximum BOD concentration of $2 \mathrm{mg} / \mathrm{L}$. Therefore, from 106.5 to $66.3 \mathrm{~km}$, the DO concentrations obtained for the return periods do not comply with the environmental quality levels, unlike the BOD concentrations, which comply with the levels established by the regulations. Finally, upstream from the Gomero River to the mechanical bridge is the monitoring area of station BI-50, which establishes a minimum DO concentration of $8.7 \mathrm{mg} / \mathrm{L}$ and a maximum 
BOD concentration of $2 \mathrm{mg} / \mathrm{L}$. Therefore, from 66.3 to $54 \mathrm{~km}$, the environmental quality standards for DO and BOD are met; however, from 54 to $32 \mathrm{~km}$, the standard levels for DO concentrations are not met. The combination of these types of tools is useful in designing water quality management plans and developing decontamination plans to understand the local situation and control surface water pollution in multiple-use watersheds.
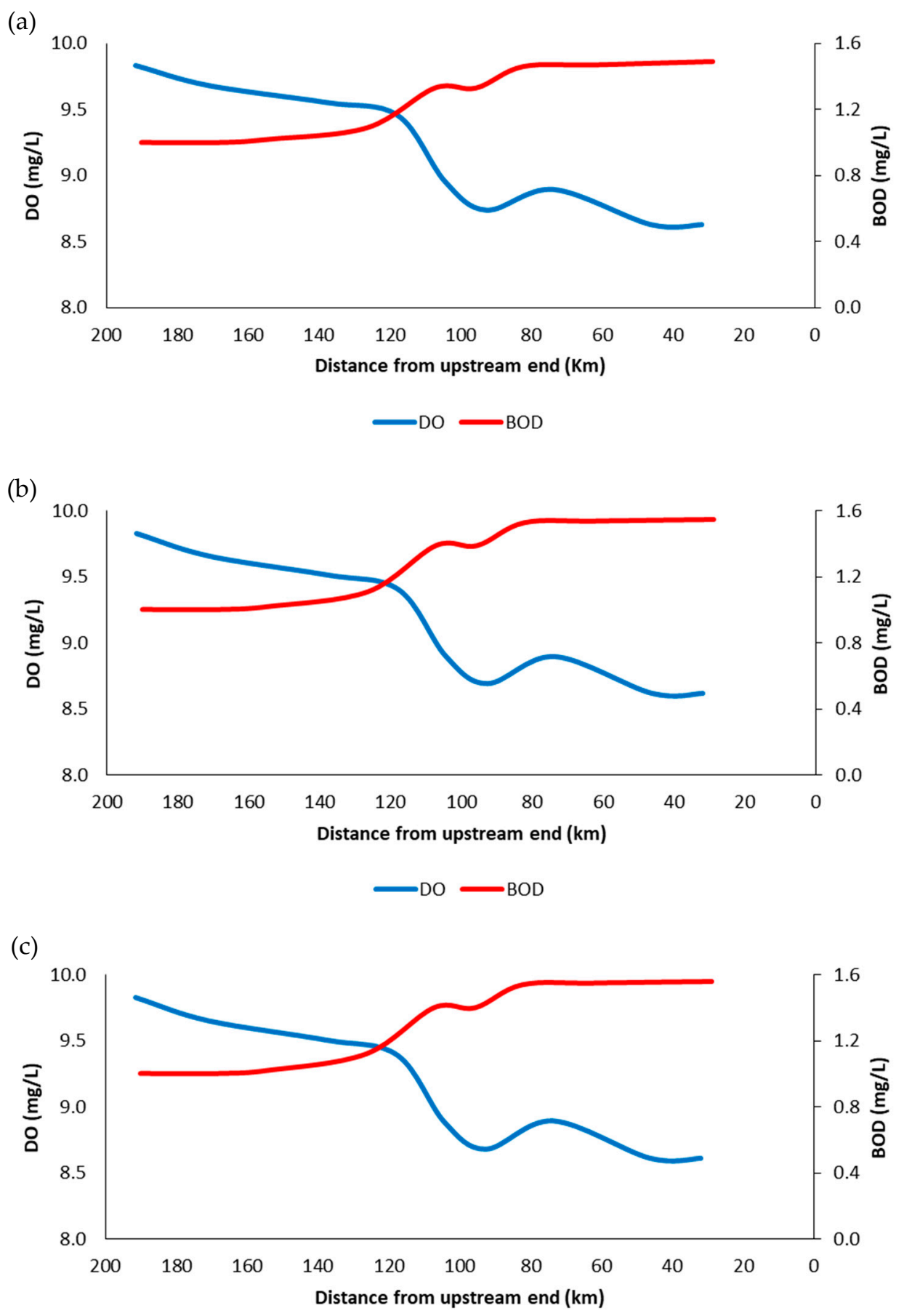

$\longrightarrow \mathrm{DO} \longrightarrow \mathrm{BOD}$

Figure 4. Modeling of $\mathrm{DO} v / \mathrm{s} \mathrm{BOD}_{5}$ concentrations for (a) 5-year return period; (b) 50-year return period, (c) 100-year return period. 


\section{Conclusions}

According to the efficiency criteria used, the predictions made by the Qual2K model are satisfactory, both in the calibration and validation phases, so this model is a good approach by estimated the Biobío River BOD load capacity.

It was found that the most influential parameters in the model response were the $\mathrm{k}_{\mathrm{a}}$ coefficient and the $\theta_{\mathrm{a}}$ factor, demonstrating that the reaeration process and temperature determine the $\mathrm{DO}$ concentrations in the river.

Based on the different extreme minimum flow scenarios, the model response indicates that the section studied has a high loading capacity for BOD, due principally to its high flows in the summer months. Therefore, under the modeled conditions, the Biobío River does not present organic matter pollution and has a high available capacity for BOD assimilation. According to the values obtained, the highest BOD loading capacity is reached in the 5-year return period for a minimum flow of $82.59 \mathrm{~m}^{3} / \mathrm{s}$ and a BOD concentration of $2078 \mathrm{mg} / \mathrm{L}$, and the lowest loading capacity is obtained in a 100-year return period, equivalent to $1580 \mathrm{mg} / \mathrm{L}$ of BOD and minimum flow of $64.32 \mathrm{~m}^{3} / \mathrm{s}$.

This study shows that the Qual2K model coupled to Hec-Ras is an effective tool for calculating the permissible BOD load capacity in the Biobío River section. The application of these models can be extended to similar problems with other contaminants such as nitrogen and phosphorus.

The results of the present investigation demonstrate that the calibration and validation of this type of tool can be of great use in the future in the planning and control of water pollution in the Biobío River, in addition to providing information on the size of BOD concentrations that may have future discharges into this receiving water body.

Author Contributions: Conceptualization, A.Z., M.A., A.S., M.E.D., R.F. and P.A.; Methodology, A.Z.; Software, A.Z.; Validation, A.Z., M.A., A.S., M.E.D. and P.A.; Writing-Original Draft Preparation, A.Z. and M.A.; Writing-Review \& Editing, A.Z., M.A., A.S., P.A., M.E.D. and R.F. All authors have read and agree with the published version of the manuscript.

Funding: This research was funded by NSFC190002 project and ANID/FONDAP/15130015.

Institutional Review Board Statement: Not applicable.

Informed Consent Statement: Not applicable.

Data Availability Statement: Data is contained within the article.

Acknowledgments: We appreciate this research was funded by NSFC190002 project and ANID/FONDAP/15130015.

Conflicts of Interest: The authors declare no conflict of interest.

\section{References}

1. WWAP. Informe Mundial de Naciones Unidas Sobre el Desarrollo de los Recursos Hidricos 2019-No Dejar a Nadie Atrás; UNESCO: Paris, Fance, 2019.

2. Hutchins, M.G.; Abesser, C.; Prudhomme, C.; Elliott, J.A.; Bloomfield, J.P.; Mansour, M.M.; Hitt, O.E. Combined impacts of future land-use and climate stressors on water resources and quality in groundwater and surface waterbodies of the upper Thames river basin, UK. Sci. Total Environ. 2018, 631-632, 962-986. [CrossRef]

3. Mack, L.; Andersen, H.E.; Beklioglu, M.; Bucak, T.; Couture, R.M.; Cremona, F.; Ferreira, M.T.; Hutchins, M.G.; Mischke, U.; Molina-Navarro, E.; et al. The future depends on what we do today-Projecting Europe's surface water quality into three different future scenarios. Sci. Total Environ. 2019, 668, 470-484. [CrossRef]

4. GEO-5. Environment for the Future We Want; UNEP: Nairobi, Kenya, 2012.

5. GEO-6. Regional Assessment for Latin America and the Caribbean; UNEP: Nairobi, Kenya, 2016.

6. WWAP. Informe Mundial de las Naciones Unidas sobre el Desarrollo de los Recursos Hídricos 2020: Agua y Cambio Climático; UNESCO: Paris, Fance, 2020.

7. Guo, D.L.; Lintern, A.; Webb, J.A.; Ryu, D.; Bende-Michl, U.; Liu, S.C.; Western, A.W. A data-based predictive model for spatiotemporal variability in stream water quality. Hydrol. Earth Syst. Sci. 2020, 24, 827-847. [CrossRef] 
8. Hernandez-Ramirez, A.G.; Martinez-Tavera, E.; Rodriguez-Espinosa, P.F.; Mendoza-Perez, J.A.; Tabla-Hernandez, J.; EscobedoUrias, D.C.; Jonathan, M.P.; Sujitha, S.B. Detection, provenance and associated environmental risks of water quality pollutants during anomaly events in River Atoyac, Central Mexico: A real-time monitoring approach. Sci. Total Environ. 2019, 669, 1019-1032. [CrossRef] [PubMed]

9. Pejman, A.H.; Bidhendi, G.R.N.; Karbassi, A.R.; Mehrdadi, N.; Bidhendi, M.E. Evaluation of spatial and seasonal variations in surface water quality using multivariate statistical techniques. Int. J. Environ. Sci. Technol. 2009, 6, 467-476. [CrossRef]

10. Mirauda, D.; Caniani, D.; Colucci, M.T.; Ostoich, M. Assessing the fluvial system resilience of the river Bacchiglione to point sources of pollution in Northeast Italy: A novel Water Resilience Index (WRI) approach. Environ. Sci. Pollut. Res. 2021, 28, 36775-36792. [CrossRef]

11. Mukundan, R.; Acharya, N.; Gelda, R.K.; Frei, A.; Owens, E.M. Modeling streamflow sensitivity to climate change in New York City water supply streams using a stochastic weather generator. J. Hydrol. Reg. Stud. 2019, 21, 147-158. [CrossRef]

12. Montes, R.T.; Navarro, I.; Domínguez, R.; Jiménez, B. Modificación de la capacidad de autodepuración del río Magdalena ante el cambio climático. Tecnol. Cienc. Agua 2013, 4, 71-83.

13. Bailey, R.T.; Ahmadi, M. Spatial and temporal variability of in-stream water quality parameter influence on dissolved oxygen and nitrate within a regional stream network. Ecol. Model. 2014, 277, 87-96. [CrossRef]

14. Bhargava, D.S. Models for Polluted Streams Subject to Fast Purification. Water Res. 1986, 20, 1-8. [CrossRef]

15. Katyal, D. Water quality indices used for surface water vulnerability assessment. Int. J. Environ. Sci. $2011,2,154-173$.

16. Fan, C.; Ko, C.H.; Wang, W.S. An innovative modeling approach using Qual2K and HEC-RAS integration to assess the impact of tidal effect on River Water quality simulation. J. Environ. Manag. 2009, 90, 1824-1832. [CrossRef]

17. Gurjar, S.K.; Tare, V. Spatial-temporal assessment of water quality and assimilative capacity of river Ramganga, a tributary of Ganga using multivariate analysis and QUEL2K. J. Clean. Prod. 2019, 222, 550-564. [CrossRef]

18. Streeter, H.W.; Phelps, E.B. A study of the pollution and natural purification of the Ohio River. III Factors concerned in the phenomena of oxidation and reaeration. Public Realt. Bull. 1925, 146, 75.

19. Ji, X.L.; Shang, X.; Dahlgren, R.A.; Zhang, M.H. Prediction of dissolved oxygen concentration in hypoxic river systems using support vector machine: A case study of Wen-Rui Tang River, China. Environ. Sci. Pollut. Res. 2017, 24, 16062-16076. [CrossRef]

20. Nagisetty, R.M.; Flynn, K.F.; Uecker, D. Dissolved oxygen modeling of effluent-dominated macrophyte-rich Silver Bow Creek. Ecol. Model. 2019, 393, 85-97. [CrossRef]

21. Xu, J.; Jin, G.Q.; Tang, H.W.; Mo, Y.M.; Wang, Y.G.; Li, L. Response of water quality to land use and sewage outfalls in different seasons. Sci. Total Environ. 2019, 696. [CrossRef]

22. Vaideliene, A.; Michailov, N. Dam influence on the river self-purification. In Proceedings of the 7th International Conference Environmental Engineering, Vilnius, Lithuania, 22-23 May 2008; pp. 748-757.

23. VishnuRadhan, R.; Zainudin, Z.; Sreekanth, G.B.; Dhiman, R.; Salleh, M.N.; Vethamony, P. Temporal water quality response in an urban river: A case study in peninsular Malaysia. Appl. Water Sci. 2017, 7, 923-933. [CrossRef]

24. Zubaidah, T.; Karnaningroem, N.; Slamet, A. The Self-Purification Ability in the Rivers of Banjarmasin, Indonesia. J. Ecol. Eng. 2019, 20, 177-182. [CrossRef]

25. Diego, C.A. Modelo de Calidad de Aguas Para Determinar la Capacidad Autodepurativa del Río BioBío de las Descargas de la Industria de la Celulosa y Papel; Universidad de Concepción: Concepción, Chile, 2001.

26. Gonzalez, S.O.; Almeida, C.A.; Calderon, M.; Mallea, M.A.; Gonzalez, P. Assessment of the water self-purification capacity on a river affected by organic pollution: Application of chemometrics in spatial and temporal variations. Environ. Sci. Pollut. Res. 2014, 21, 10583-10593. [CrossRef]

27. Chi, M.; Zhang, D.; Fan, G.; Zhang, W.; Liu, H. Prediction of water resource carrying capacity by the analytic hierarchy process-fuzzy discrimination method in a mining area. Ecol. Indic. 2019, 96, 647-655. [CrossRef]

28. Darmian, M.D.; Khodabandeh, F.; Azizyan, G.; Giesy, J.P.; Hashemi Monfared, S.A. Analysis of assimilation capacity for conservation of water quality: Controllable discharges of pollutants. Arab. J. Geosci. 2020, 13, 888. [CrossRef]

29. Camacho, R.A.; Martin, J.L.; Wool, T.; Singh, V.P. A framework for uncertainty and risk analysis in Total Maximum Daily Load applications. Environ. Model. Softw. 2018, 101, 218-235. [CrossRef]

30. Chang, C.L.; Hong, T.Y. Applying environmental models to determine total maximum daily loads for reservoir watershed management. Int. J. Environ. Sci. Technol. 2019, 16, 5635-5642. [CrossRef]

31. Xu, Y.L.; Bosch, D.J.; Wagena, M.B.; Collick, A.S.; Easton, Z.M. Meeting Water Quality Goals by Spatial Targeting of Best Management Practices under Climate Change. Environ. Manag. 2019, 63, 173-184. [CrossRef]

32. Fan, C.H.; Chen, K.H.; Huang, Y.Z. Model-based carrying capacity investigation and its application to total maximum daily load (TMDL) establishment for river water quality management: A case study in Taiwan. J. Clean. Prod. 2021, 291, 125251. [CrossRef]

33. Patil, A.; Deng, Z.Q.; Malone, R.F. Temporal scale-induced uncertainty in load duration curves for instream-dissolved oxygen. Environ. Monit. Assess. 2013, 185, 1939-1949. [CrossRef]

34. Wang, X.Y.; Pang, S.J.; Yang, L.; Melching, C.S. A framework for determining the maximum allowable external load that will meet a guarantee probability of achieving water quality targets. Sci. Total Environ. 2020, 735, 139421. [CrossRef]

35. Zhang, R.B.; Gao, H.L.; Zhu, W.T.; Hu, W.; Ye, R. Calculation of permissible load capacity and establishment of total amount control in the Wujin River Catchment-a tributary of Taihu Lake, China. Environ. Sci. Pollut. Res. 2015, 22, 11493-11503. [CrossRef] 
36. Antunes, I.M.H.R.; Albuquerque, M.T.D.; Oliveira, S.F.; Sánz, G. Predictive scenarios for surface water quality simulation-A watershed case study. Catena 2018, 170, 283-289. [CrossRef]

37. Nguyen, H.D.; Hong Quan, N.; Quang, N.X.; Hieu, N.D.; Thang, L.V. Spatio-temporal pattern of water quality in the Saigon-Dong Nai river system due to waste water pollution sources. Int. J. River Basin Manag. 2021, 19, 221-243. [CrossRef]

38. Fajardo, M.I.A.D.; Agudelo, V.M.S.R.N. Simulación de calidad del agua en un tramo de la sub-cuenca río alto Bogotá en el periodo 2014-2016 a partir del modelo HEC-RAS. Rev. Colomb. Cienc. Anim. Recia 2019, 11, 43-55.

39. Halaj, P.; Barek, V.; Veliskova, Y.P.; Barekova, A.P.; Pechacova, K.; Stredanska, A. Longitudinal Dispersion Coefficient Impact Assessment On HEC-RAS Water Quality Model Outputs. In Proceedings of the International Multidisciplinary Scientific GeoConference: SGEM, Albena, Bulgaria, 16-22 June 2013; pp. 213-220.

40. Olaoye, I.A.; Confesor, R.B.; Ortiz, J.D. Impact of Seasonal Variation in Climate on Water Quality of Old Woman Creek Watershed Ohio Using SWAT. Climate 2021, 9, 50. [CrossRef]

41. Woo, S.-Y.; Kim, S.-J.; Lee, J.-W.; Kim, S.-H.; Kim, Y.-W. Evaluating the impact of interbasin water transfer on water quality in the recipient river basin with SWAT. Sci. Total Environ. 2021, 776, 145984. [CrossRef]

42. Bui, H.H.; Ha, N.H.; Nguyen, T.N.D.; Nguyen, A.T.; Pham, T.T.H.; Kandasamy, J.; Nguyen, T.V. Integration of SWAT and QUAL2K for water quality modeling in a data scarce basin of Cau River basin in Vietnam. Ecohydrol. Hydrobiol. 2019, 19, 210-223. [CrossRef]

43. Arriagada, P.; Dieppois, B.; Sidibe, M.; Link, O. Impacts of Climate Change and Climate Variability on Hydropower Potential in Data-Scarce Regions Subjected to Multi-Decadal Variability. Energies 2019, 12, 2747. [CrossRef]

44. Bolinches, A.; De Stefano, L.; Paredes-Arquiola, J. Designing river water quality policy interventions with scarce data: The case of the Middle Tagus Basin, Spain. Hydrol. Sci. J. 2020, 65, 749-762. [CrossRef]

45. Shah, M.I.; Javed, M.F.; Abunama, T. Proposed formulation of surface water quality and modelling using gene expression, machine learning, and regression techniques. Environ. Sci. Pollut. Res. 2021, 28, 13202-13220. [CrossRef]

46. Yevenes, M.A.; Figueroa, R.; Parra, O. Seasonal drought effects on the water quality of the Biobio River, Central Chile. Environ. Sci. Pollut. Res. 2018, 25, 13844-13856. [CrossRef]

47. Parra, O.; Figueroa, R.; Valdovinos, C.; Habit, E.; Díaz, M.E. Programa de Monitoreo de la Calidad del Agua del Sistema río Biobío 1994-2012: Aplicación del Anteproyecto de Norma de la Calidad del Agua del río Biobío, Concepción; Universidad de Concepción: Concepción, Chile, 2013.

48. EULA-Chile, C. Centro EULA-Chile: Evolución y Perspectivas a 30 Años de su Creación; Universidad de Concepción (Chile); EULA-CHILE. Centro de Ciencias Ambientales: Concepción, Chile, 2020.

49. Díaz, M.E.; Figueroa, R.; Alonso, M.L.S.; Vidal-Abarca, M.R. Exploring the complex relations between water resources and social indicators: The Biobío Basin (Chile). Ecosyst. Serv. 2018, 31, 84-92. [CrossRef]

50. DGA. Dirección General de Aguas. Información Oficial Hidrometeorológica y de Calidad de Aguas en Línea. Available online: https://snia.mop.gob.cl/BNAConsultas/reportes (accessed on 1 September 2014).

51. Melo, O.; Perez, J. Water Quality Policy. In Water Policy in Chile; Donoso, G., Ed.; Springer International Publishing: Cham, Switzerland, 2018; pp. 87-102.

52. Decree-Decreto $\mathrm{N}^{\circ}$ 9. Norma Secundaria de Calidad Ambiental para la Protección de las Aguas Continentales Superficiales de la Cuenca del Río Biobio; Ministerio de Medio Ambiente, Gobierno de Chile: Santiago, Chile, 2015.

53. Long, B.T. Inverse algorithm for Streeter-Phelps equation in water pollution control problem. Math. Comput. Simul. 2020, 171, 119-126. [CrossRef]

54. Churchill, M.A. Analysis of a Stream's Capacity for Assimilating Pollution. Sew. Ind. Wastes 1954, 26, 887-904.

55. Kannel, P.R.; Kanel, S.R.; Lee, S.; Lee, Y.S.; Gan, T.Y. A Review of Public Domain Water Quality Models for Simulating Dissolved Oxygen in Rivers and Streams. Environ. Model. Assess. 2011, 16, 183-204. [CrossRef]

56. Khorashadizadeh, M.; Azizyan, G.; Monfared, S.A.H.; Akbarpour, A.; Shabani, A. A timetable and spatial planning for pollutant entrance to the river. Int. J. Environ. Sci. Technol. 2020, 17, 4171-4188. [CrossRef]

57. Mcbride, G.B. Nomographs for Rapid Solutions for the Streeter-Phelps Equations. J. Water Pollut. Control Fed. 1982, 54, 378-384.

58. Nuruzzaman, M.; Al-Mamun, A.; Bin Salleh, M.N. A Modified Laboratory Approach to Determine Reaeration Rate for River Water. Arab. J. Sci. Eng. 2018, 43, 2037-2051. [CrossRef]

59. Reckhow, K.H. Water-Quality Simulation Modeling and Uncertainty Analysis for Risk Assessment and Decision-Making. Ecol. Model. 1994, 72, 1-20. [CrossRef]

60. Sharma, D.; Kansal, A.; Pelletier, G. Water quality modeling for urban reach of Yamuna river, India (1999-2009), using QUAL2Kw. Appl. Water Sci. 2017, 7, 1535-1559. [CrossRef]

61. Zhang, R.B.; Qian, X.; Li, H.M.; Yuan, X.C.; Ye, R. Selection of optimal river water quality improvement programs using QUAL2K: A case study of Taihu Lake Basin, China. Sci. Total Environ. 2012, 431, 278-285. [CrossRef]

62. Abdeveis, S.; Sedghi, H.; Hassonizadeh, H.; Babazadeh, H. Application of Water Quality Index and Water Quality Model QUAL2K for Evaluation of Pollutants in Dez River, Iran. Water Resour. 2020, 47, 892-903. [CrossRef]

63. Chapra, S.C.; Pelletier, G.J.; Tao, H. QUAL2K: A Modeling Framework for Simulating River and Stream Water Quality, Version 2.11: Documentation and Users Manual; Civil and Environmental Engineering Dept., Tufts University: Medford, MA, USA, 2008.

64. Cho, J.H.; Ha, S.R. Parameter optimization of the QUAL2K model for a multiple-reach river using an influence coefficient algorithm. Sci. Total Environ. 2010, 408, 1985-1991. [CrossRef] 
65. Walling, B.; Chaudhary, S.; Dhanya, C.T.; Kumar, A. Estimation of environmental flow incorporating water quality and hypothetical climate change scenarios. Environ. Monit. Assess. 2017, 189, 861. [CrossRef]

66. U.S. Department of the Interior. U.S.G.S. Earth Explorer. Available online: https://earthexplorer.usgs.gov/ (accessed on 1 September 2014).

67. Moriasi, D.N.; Arnold, J.G.; Van Liew, M.W.; Bingner, R.L.; Harmel, R.D.; Veith, T.L. Model evaluation guidelines for systematic quantification of accuracy in watershed simulations. Trans. Asabe 2007, 50, 885-900. [CrossRef]

68. Moriasi, D.N.; Gitau, M.W.; Pai, N.; Daggupati, P. Hydrologic and Water Quality Models: Performance Measures and Evaluation Criteria. Trans. Asabe 2015, 58, 1763-1785. [CrossRef]

69. Parajuli, P.B.; Nelson, N.O.; Frees, L.D.; Mankin, K.R. Comparison of AnnAGNPS and SWAT model simulation results in USDA-CEAP agricultural watersheds in south-central Kansas. Hydrol. Process. 2009, 23, 748-763. [CrossRef]

70. Hadiani, M.; Asl, S.J.; Banafsheh, M.R.; Dinpajouh, Y. Investigation on the Effect of the Season in Determination of Manning Roughness Coefficient in Predicting Drought Hydraulic Behavior (Case Study: Haraz River). World Appl. Sci. J. 2013, 22, 307-312.

71. Norma Chilena Oficial. NCh 1333/1987. Requisitos de calidad de agua para diferentes usos. Available online: https:/ / ciperchile. cl/pdfs/11-2013/norovirus/NCh1333-1978_Mod-1987.pdf (accessed on 20 October 2014).

72. Langbein, W.B.; Durum, W.H. The Aeration Capacity of Streams; US Department of the Interior, Geological Survey: Washington, DC, USA, 1967; Volume 542.

73. Bowie, G.L.; Mills, W.B.; Porcella, D.B.; Campbell, C.L.; Pagenkopf, J.R.; Rupp, G.L.; Johnson, K.M.; Chan, P.; Gherini, S.A.; Chamberlin, C. Rates, constants, and kinetics formulations in surface water quality modeling. Environ. Prot. Agency 1985, 600, 3-85.

74. Link, O. Estimación de la capacidad de Reaireación en Ríos, Aplicación al Río Bío Bío, Informe Memoria de Título Para Optar al Título de Ingeniero Civil; Universidad de Concepción: Concepción, Chile, 1998.

75. Anderson, T.W.; Darling, D.A. Asymptotic Theory of Certain "Goodness of Fit" Criteria Based on Stochastic Processes. Ann. Math. Stat. 1952, 23, 193-212. [CrossRef]

76. Valdovinos, C.; Parra, O. La cuenca del río Biobío: Historia natural de un ecosistema de uso múltiple. Publ. Cent. EULA 2006, $1-25$. 